\title{
Cumulative effects of nitrogen additions on litter decomposition in three tropical forests in southern China
}

\author{
Hua Fang • Jiangming Mo • Shaolin Peng • \\ Zhian Li • Hui Wang
}

Published online: 26 February 2009

(C) Springer Science + Business Media B.V. 2009

Erratum to: Plant Soil (2007) 297:233-242

DOI 10.1007/s11104-007-9339-9

The originally published reference list of this article unfortunately contained a mistake. The correct reference is shown here:

\section{Reference}

Andersson M, Kjoller A, Struwe S (2004) Microbial enzyme activities in leaf litter, humus and mineral soil layers of European forests. Soil Biol Biochem 36:1527-1537

Responsible Editor: Alfonso Escudero.

The online version of the original article can be found under doi:10.1007/s11104-007-9339-9

H. Fang $\cdot$ J. Mo $(\bowtie) \cdot$ S. Peng $\cdot$ Z. Li $\cdot$ H. Wang

South China Botanical Garden,

The Chinese Academy of Sciences,

Dinghu, Zhaoqing, Guangdong 526070, China

e-mail: mojm@scib.ac.cn

H. Fang

Guangzhou Institute of Geography,

Guangzhou, Guangdong 510070, China

H. Fang $\cdot$ H. Wang

The Graduate University of Chinese Academy of Sciences,

Beijing 100039, China

S. Peng

School of Life Sciences, Sun Yat-sen University,

Guangzhou 510275, China 